\title{
The Research on Enterprise Management Innovation --- Based on the Study of Small and Medium Sized Family Enterprises
}

\author{
Qian Luo ${ }^{1} \&$ Xilin Liu ${ }^{1}$ \\ ${ }^{1}$ School of Management, Shanghai University of Engineering Science, Shanghai, China \\ Correspondence: Qian Luo, Wenhui Road 800 Lane, The 56th building, Room 306, Songjiang University Town, \\ Songjiang District, Shanghai, China. E-mail: 438453100@qq.com, luoqianjj@yeah.net
}

Received: November 14, 2013

Accepted: November 25, $2013 \quad$ Online Published: February 16, 2014

doi:10.5430/jms.v5n1p49

URL: http://dx.doi.org/10.5430/jms.v5n1p49

\begin{abstract}
The small and medium sized family enterprises in China have developed rapidly since the reform and opening up.Numerous facts show that the family management is reasonable and proper in the early development of small and medium-sized family enterprise. However, with the further development of family enterprise, the shortcomings of family management are exposed and have become obstacles which restrict the development of enterprise, as a result, the research and analysis in the management problems of small and medium sized family enterprises has become one of the most important research projects to solve the problem of the sustainable development of family enterprises in China. Based on the above considerations, this article puts forward a "person" as the core, takes concept innovation, strategic innovation, cultural innovation, institutional innovation and organizational innovation as the main content of management innovation idea, and brings forward the correspondingly appropriate countermeasures in solving the existing family management problems in small and medium-sized family enterprises.
\end{abstract}

Keywords: small and medium-sized family enterprises, family-based management, management innovation

\section{Research Background}

The paper is researched under the background of state-owned enterprises scaling down, private enterprises surging in high-growth, small and medium-sized family enterprises growing rapidly, at the same time, facing the quick perish.Since reform and opening, China's family enterprises have developed rapidly. According to the 2010 to 2011 annual "China's private economy development situation analysis"that was reported by the National Federation: the number of private enterprises has had an obvious growth since 2005. By the end of 2010, the number of China's registered private enterprises was more than 8.4 million, with a average annual growth rate of $14.3 \%$, private enterprises have become China's largest enterprise groups, accounting for $74 \%$ of the total number of the enterprises. According to the related statistics show: more than $90 \%$ in China's private enterprise is a family business, and most of them implement family management; it shows that from 2010 Democratic National Construction Association's Special Research Report "the survey and suggestions of small and medium-sized enterprises' transformation and innovation in the post-crisis era", the average life expectancy was only 3.7 years at present, $80 \%$ of which are family businesses. Family enterprises are the body of private enterprises, are the absolute main force in the non-public economy. The rapid development of family business has become an important phenomenon in China's economic life since the reform and opening up. It is playing an important role in achieving full employment, promoting social economic growth, improving people's living standards and promoting the development of social market economy, and become an integral part of the socialistic market economy. However, the development situation of private enterprises in China still is not optimistic. Many small and medium-sized family enterprises ruin soon after a period of development, although there are some enterprises developing well in a short time, have not yet escaped the fate of a flash in the pan.

When an enterprise is in its infancy, the family business with traditional family management has the incomparable cost advantage and competitive advantage. But with the scale of the family business expanding to a certain extent, the disadvantages of the traditional family management highlight out gradually, such as:arbitrary decision-making making mistakes easily, the loss of talented people and difficult to integrate into the family business, the narrow financing channel for enterprises, business risks increasing and inheritance rights existing problems and so on. The way of traditional family management has been difficult to meet the need of enterprise's continuing development. A 
research report about the competitiveness and future development strategy of private enterprises shows that: among so many obstacles factors that restrict the large development of private enterprises, family-based management is an important factor restricting the development of small and medium-sized family firms. Therefore, how to effectively conduct the management innovation is the problem to need to be solved in the development process of small and medium-sized family enterprises.

\section{Research Significance}

The significance of this research embodies in the following aspects: firstly, it provides a theoretical basis for sustainable development of small and medium-sized family enterprises. After a difficult start stage, most of small and medium-sized family enterprises in China develop very rapidly, and quickly grows into certain scale enterprises, but with the expansion of enterprise scale and business, there appears a series of questions in the meanwhile, such as: talent not keeping up with the need of development, technology not keeping up with the market need and finance challenging and so on, small and medium-sized family enterprises are in urgent need of changing management thinking and implementing innovative strategies to ensure that enterprises can continue to run well. Management innovation requires small and medium-sized family firms identify the current situation, recognize own shortcomings, re-optimize the existing resources to improve operational efficiency. As small and medium-sized family enterprises lack of high-level personnel, it is difficult to have a systematic methods and theories to guide them for the effective management innovation activities. Therefore, the current academic research for small and medium-sized family enterprises is very necessary, especially it is particularly urgent to explore a theory that is suitable for the development of small and medium-sized family enterprises in China's national conditions. Secondly, it provides a practical reference for the management innovation of small and medium-sized family enterprises. Most private enterprises are family businesses at present in China. They have encountered the same or similar management bottlenecks in the development process, how to carry out effective management innovation is an urgent problem to be solved in the family business. This article is for the use of management innovation theory, also, the summary of management innovation practice activity, so, to some extent, the thesis provides a practical reference for the management innovation of small and medium-sized family enterprises.

\section{Theoretical Basis-Enterprise Management Innovation Theory}

In today's knowledge economy era, the personalization, differentiation, and segmentation of market demand are continuously strengthening in the general trend of the market. At the same time, the expanding speed of market accelerating, globalization and integration deepening. What is more, with the transparency of market information deepening and the information technology speeding up, that lead to new products' research and development speeding up and product update cycle becoming shorter. In order to adapt to the rapidly changing market, enterprises need to accelerate the innovation in manpower, resources, technology and management to meet the demand of market. This process to adapt to market changes is the process of management innovation, and management innovation is a systematic innovation behavior, not a local behavior.Management innovation theory is mainly manifested in the following aspects: firstly, management innovation motivation stage. Secondly, management innovation preparation phase. Thirdly, innovative program design phase. Fourthly, management innovation program implementation phase. Finally, management innovation program evaluation and feedback correction phase.

It can be learned from the processes of management innovation activities above: management innovation is a systematic management process, by that, an organization can effectively deploy and integrate the enterprise's existing resources to achieve enterprise's stated goals, its core is to effectively integrate resources to achieve organizational stated goals. Organization to effectively integrate resources will involve many aspects and is affected by various factors, the process of solving these problems is the upgrade process of management innovation, and dealing with these issues is the management itself. The concept of management innovation and management are inseparable, so, from the point of view of management, management innovation is to integrate internal and external resources in order to more effectively achieve organizational goals and responsibility and improve organizational efficiency by using the new or more effective methods.

\section{Problems Analysis of Management Innovation}

\subsection{Management Features in Small and Medium Sized Family Enterprises}

In the process of development of small and medium-sized family enterprises in China, the family enterprise management presents its own characteristics, mainly manifested in the following aspects: firstly, enclosed property right structure. Small and medium-sized family enterprises are mostly mom-and-pop stores or self-employed at present in China, have strong family characteristics and its property rights are mostly owned by family members, its 
feature is the uniqueness of property possession and the exclusiveness of property ownership. Secondly, Family Business Management set ownership and management rights in one. In the small and medium-sized family firms, Business owners put a very high value on the control of the company, are not willing to hand over the control right to other people, most family business owners are both chairman and general manager, set the ownership and management in one and implement the paternalistic leadership, enterprise's executive power, supervision and decision rights are controlled by business owners and their family members. What is more, corporate ownership and control in the small and medium-sized family enterprises just pass within the family, employees outside the family simply can not have a real management right, let alone ownership. Thirdly, obvious cronyism and preface-structure.In the absence of comprehensive employment and incentive mechanism, the Chinese family business is highly affected by the traditional kinship, staff into the family enterprise mostly rely on family relationship, the appointment of managers in small and medium-sized family enterprises also has a strict preface-structure, that depends on blood relationship and loyalty for business owners. Fourthly, highly centralized paternalistic leadership decision-making.Small and medium-sized family business in its startup is a family operation, entrepreneur is a patriarchal figure, and business owners tend to show parentally centralized leadership style in the shadow of parental authority. Fifthly, humanized instead of institutionalized management.Since its entrepreneurship, small and medium-sized family firm is to act according to the command of entrepreneurs, family members help each other in a blood or kinship relationship, everyone works hard, makes plans and give advices for the development and growth of family enterprise regardless of the return. Business owners are also concerned about the subordinate employees as the role of parents, enterprise do not have the system, employees think it is not necessary to use rules constraint themselves, very consciously abide by the unwritten rules, and will not cause any damage to the enterprise.Sixthly, one more duty, low operational efficiency in enterprise. One more post appears to save labor costs, but actually reduces operating efficiency and increases the company's operating costs. Finally, stronger the family influence, more difficult the business transformation. The quality of family members far couldn't keep up with the demand of enterprise development while the enterprise develop rapidly, in the meanwhile, members of the family are not willing to withdraw from the management positions, give way to "outsiders", so, family members will impose an anti-reform coalition to prevent the innovation of enterprise management. Therefore, the management innovation will be more difficult because of the powerful family influence in the small and medium-sized family enterprise.

\subsection{Factors Analysis of Affecting Management Innovation}

Firstly, social and political system influencing the management innovation. Due to the role of historical tradition, institutional inertia, war, social requirements and human factors,social and political system deeply affects the management system of small and medium-sized family firms. The Country imposes strict restrictions on private enterprises, that results in private enterprises' difficult survival. Secondly, social and economic conditions influencing the management innovation. The survival and development of small and medium sized family businesses is an important supplement to social economy, playing an important role in expanding employment balancing social security. There is a lack of trusted market environment, the professional manager market is imperfect, and resources are scarce in China, at the same time, the family business in this historical stage is an important form of business organization, the combined effect of these factors makes the social and economic conditions to bring about a significant impact on small and medium-sized family business management. Thirdly, social and traditional culture influencing the management innovation. Thousands of years of Chinese traditional culture has deeply influenced the lifestyle, thought and behavior of modern people, at the same time, affecting the family business, especially small and medium-sized enterprises, so, there existing a serious humanized management in most small and medium-sized enterprises. The family business must be good at combining the Western advanced management thoughts while giving full play to the role of traditional culture. However, family businesses also can't copy the western management theory, they must combine the western management theory with Chinese actual conditions and gradually targeted deepen the management innovation step by step. Finally, social legal environment influencing the management innovation. Because China is in the social transition, a variety of legal systems need to be improved and perfected. But, The overall trend of social legal environment is getting better, and the legal system is bound to comply with the direction of development of small and medium-sized enterprises. The traditional idea of love above law should be gradually changed, the sound of rule of law society will promote the institutional construction of enterprise and the establishment of modern enterprise system. There is still a lack of perfect laws to protect the family businesses, it is mainly manifested in the following two aspects: firstly, the private family enterprises lack of property rights protection; Secondly, there is not a sound system of private enterprise financing and legal security system in China, that led to the absence of good financing channels in the private enterprise. 


\section{Conclusions and Research Outlook}

\subsection{Conclusions}

Firstly, family businesses often experienced from start-up period, development period, mature period to out of the life cycle stage.In the life cycle, its management model is also experiencing the life cycle process from infancy, toddler, adolescence, prime of life to transformation. And corresponding with the life-cycle, the management form of family business also has experienced the process from the paternalistic leadership, family-based, family-owned to professional managers, some may have experienced a leap development. However, its management is gradually mature along with the development of family enterprise.

Secondly, there are still many problems in the management innovation of small and medium-sized family enterprises in China, such as, relying too much on the traditional family system,family forces more powerful, sectarian ideas serious, a larger proportion of family members, the traditional culture restricting obviously, low quality of family management personnel, the lack of a scientific and effective management, the lack of strategic management awareness and unsystematic management innovation and so on, these problems above cause that it is difficult to realize the innovation of the management mode of small and medium-sized family firms. This paper argues that the biggest problem of management innovation in China's current small family enterprises exists in human resources management. Talent is the most important resource, all the innovation is inseparable from the support of talent development, how to effectively develop the talent is a required course for every family enterprise that wants to do stronger and bigger.

Thirdly, the management innovation of small and medium-sized family firms in China should take concept innovation, strategy innovation, culture innovation, system innovation and organizational innovation as the main content.

Fourthly, the followings must be done in the small and medium-sized family firms. On the one hand, improve the management system of enterprise, make a good strategic planning about enterprise's development, establish the basic conditions for modern enterprise management; on the other hand, handle the relationship between family members and outsiders, complete the division of functions and powers, boldly introduce the foreign professional management personnel and go a professional management road.

Finally, the management model of family business in small and medium-sized enterprises still has the advantages of its existence. Although this is an era of emphasizing on establishing a modern enterprise management system, this paper still reiterates the advantages of family management at the end of it, as a matter of fact, many small and medium sized family businesses are steady and strongly rising and developing in a healthy state, which clearly proves the rationality and reference of its existence and development.

The following four points are a precondition for the survival and development of small and medium sized family businesses: (1) there is no maturely developing market economy; (2) the national policy environment and legal environment is still not sufficient to protect the management specialization of family business; (3) the professional manager market is imperfect and limited; (4) family business is still in the stage of small and medium scale.

In the current social conditions, family business has obvious advantages in the following respects: (1) timely and decisive decision-making, clear and unified goal. In the current stage of information market, information is wealth, information is business opportunity. Who has had first-hand information, who has rapidly responded to the information, who will grasp the wealth of business opportunities and dominate the market. Family business owners tend to be dictatorial, immediately call the family members to implement the decisions after decisions, to be courageous and able to quickly respond to the market information and have specific goals. (2) Reduce moral hazard and the transaction costs.Influenced by traditional culture, Chinese people like to be boss, always think that they are better than others, always think that they can also be independent entrepreneurs, is better than others do, so, brain drain is very serious in a lot of small and medium-sized family enterprises and has brought huge disaster to the enterprises' human resources, that is why the small and medium-sized family business owners do not easily hire outsiders and not easily hand over management rights to the professional managers. It is understandable for the owners in small and medium-sized family businesses to carefully use alien employees in order to reduce the harm of moral risk to enterprise, what is more, in the case of the absence of peripheral legal environment constraints and internal control incentive mechanism, the transaction costs of business owners hiring professional managers even are much higher than the value created by professional managers. (3) Efficient organization and controlled personnel costs. In general, the organizational structure of small and medium-sized family enterprises is flat, the speed of manager's orders delivered to the lower staff is very fast, execution speed also fast, the speed of lower level of 
employees reporting to the higher authorities also is very fast, which has greatly improved the operational efficiency of enterprise. In addition, employees' benefits and business interests are closely linked in the family business, so, when the family enterprise is in a difficult period, its employees can work without pay, tide over the difficulties with the enterprise in common, in a certain extent, the enterprise has a very strong controllability on staff costs.

The family business, of course, is only a model in the early stage of enterprise development, the healthy development of family enterprise is not only affected by the external environment, but also influenced by family members' comprehensive quality. Family business as a unique existing way of enterprise, there are many successful cases in the family enterprises both at home and abroad, such as the DuPont in United States and the Hope Group in China, which are evolved from the family business. However, when the family enterprise develops to a certain scale, it is necessary for family enterprise to keep in accordance with the modern enterprise system, otherwise it is difficult for family enterprise to survive a long term.

Most of the current small and medium-sized family firms will continue to use the family way to manage enterprise for a long time in the future, but it is only the best model selection at the beginning of enterprise development, the sustainable and healthy development of small and medium-sized family enterprises is affected not only by external environmental factors, but also depends on whether the overall employees' comprehensive quality matches the enterprise development or not. Small and medium-sized family firms can also develop into large and medium-sized enterprises and multinational groups, which has been well illustrated at home and abroad.Such as, America's Wal-Mart, Japan's Toyota and China's Hope Group, they are now still in the nature of family enterprise, but they are unceasingly growing up gradually through the management innovation, most large family businesses are in the way to the road of modern enterprise management, gradually realize the management specialization.

\subsection{Research Outlook-The Future of Small and Medium-Sized Family Enterprises}

Currently many scholars believe that it can solve the existing problems in small and medium-sized family enterprises when they transform from family-oriented to professionalism. At the same time, many authorities also believe that there is not a way out unless the professional management is carried out in the long future. They concluded the family-oriented features: complete task-oriented sales. Operation teams with blood as a link, powerful leaders, a high degree of unity in ownership and control, lack of operating mode and less clear responsibilities and rights system and so on. At present, the management and system in most small and medium-sized family enterprises is relatively backward than the modern enterprise system in fashion now. Hwever, the future development direction of family businesses is not fully professional, but should be socialized. There are some main steps for the socialization of development in small and medium-sized family enterprises: first move the distribution rights and then move the stock equity; first move the increment and then move the stock. The characteristic of the modern enterprise management system is that the enterprise is not enterprise is not controlled by an entrepreneur, but controlled by a group of entrepreneurs, and which is the most important system transformation to solve the managers' loyalty in the development process of small and medium-sized family firms.

\section{References}

An, Linbo. (2004). The existence of Chinese family businesses and the research of management professionalism. Wuhan: Wuhan University, 29-42.

Bao, Shidi. (2000). Family Business Development Research. Chongqing: Chongqing University, 13-15.

$\mathrm{Fu}, \mathrm{Xi}$. (2003). The revelation of family enterprise system. Shanghai Economy, (5), 60-61.

Holland, P.G., \& Boulton, W.R. (1984). Balancing the Family and the Business in Family Business. Business Horizons, 27(2), 16-21.

Joe, Tidd, John, Bessant, \& Keith, Pavitt. (2006). Managing Innovation ( $3^{\text {rd }}$ ed.). A Butterworth - Heinemann Title, pp.267-285.

Li, Hongyan. (2001). Talk about the enterprise management innovation in China. Yunnan: Yunnan Normal University, 8-27.

Li, Hui. (2004). Family Business Governance Mode and Optimization. Shanxi: Northwestern Polytechnical University, 12-49.

Li, Yajie. (2009). Research on the Inheritance problems and countermeasures of family businesses in China. Beijing: China University of Petroleum, 10-24.

Liu, Juxiang. (2005). Family business management pattern analysis in China. Hunan: Xiangtan University, 12-25. 
Liu, Yan. (2004). Family Enterprise Management and Development in China. Hubei: Central China Normal University, 10-25.

$\mathrm{Lu}$, Xianwen, \& Li, Enqiang. (2008). The enlightenment of non-family management of foreign enterprises. Scanning of finance and economics, 51-52.

Manfred, F. R., \& Kets de Vries. (1997). Family Business: Human Dilemmas in the Family Firm. Boston: ITB Press, pp.25-87.

Parrie, S.K. (1993). Local initiative and national reform: The Wenzhou model of development. China Quarterly, 134, $242-63$.

Ping, Xinyao. (2004). The research of family businesses in China. Nanjing: Nanjing University of Science and Technology, 7-30.

Richard, K. Hay. (2003). A Holistic Management Model for Facing the New Competitive World. Sam Advanced Management Journal, 3, 67.

Robert, G. Donnely. (1964). The Family Business. Hard Business Review, 8-17.

Shu, Changjun, Li, Yuhai, \& Zhou, Shengliang. (2010). Enterprise management innovation evaluation mechanism research. Technology Progress and Policy, 27(4), 120-123

Thomas, P., \& Rancour, S.H.E. (2005). Management Systems \& Business Integration. Professional safety, (26), 76-84.

Zhang, Xueyin. (2009). Several enterprise management innovation focuses. Leadership Science, 57-58.

Zhuang, Na. (2003). Family business groups in Japan. Beijing: Foreign Economic and Trade University, 10-15. 